\title{
Ecosystem-Based Marine Spatial Planning: An Approach to Marine and Coastal Area Management in Southernmost Brazil
}

\author{
Paulo H. Mattos ${ }^{1,}$, Jean A. Espinoza ${ }^{2}$, Raphael M. Pinotti ${ }^{3}$, João L. Nicolodi ${ }^{1}$, Lauro J. Calliari ${ }^{1}$, \\ Kahuam S. Gianuca ${ }^{4}$ \\ ${ }^{1}$ Geological Oceanography Laboratory, Institute of Oceanography, Federal University of Rio Grande - FURG, Rio Grande, Brazil \\ ${ }^{2}$ Federal Institute of Science, Technology and Education - IFSC, Caçador, Santa Catarina, Brazil \\ ${ }^{3}$ Macrobenthic Ecology Laboratory, Institute of Oceanography, Federal University of Rio Grande - FURG, Rio Grande, Brazil \\ ${ }^{4}$ Coastal Management Laboratory, Institute of Oceanography, Federal University of Rio Grande - FURG, Rio Grande, Brazil
}

Received May 11, 2021; Revised July 21, 2021; Accepted August 22, 2021

\section{Cite This Paper in the following Citation Styles}

(a): [1] Paulo H. Mattos, Jean A. Espinoza, Raphael M. Pinotti, João L. Nicolodi, Lauro J. Calliari, Kahuam S. Gianuca, "Ecosystem-Based Marine Spatial Planning: An Approach to Marine and Coastal Area Management in Southernmost Brazil," Natural Resources and Conservation, Vol. 9, No. 2, pp. 9 - 19, 2021. DOI: 10.13189/nrc.2021.090201.

(b): Paulo H. Mattos, Jean A. Espinoza, Raphael M. Pinotti, João L. Nicolodi, Lauro J. Calliari, Kahuam S. Gianuca (2021). Ecosystem-Based Marine Spatial Planning: An Approach to Marine and Coastal Area Management in Southernmost Brazil. Natural Resources and Conservation, 9(2), 9 - 19. DOI: 10.13189/nrc.2021.090201.

Copyright $\odot 2021$ by authors, all rights reserved. Authors agree that this article remains permanently open access under the terms of the Creative Commons Attribution License 4.0 International License

\begin{abstract}
One of the great challenges faced due to current human demands is to reconcile the conservation of the innumerable natural resources present in the marine realm with the intense development processes occurring in the coastal zones. The latter aspect includes Marine Spatial Planning (MSP), an important management tool created to establish a more rational organization of the use of marine and coastal areas, equalizing the demands of development with the need to protect these ecosystems. Some of the most important international organizations the European Union, OSPAR, HELCOM/VASAB, and the International Council for the Exploration of the Sea (ICES) - are encouraging MSP at a national level. Another efficient tool is Ecosystem-based Management (EBM), which allows a full arrangement of interactions within the marine realm and effectively integrates science and governance for the management of natural resources. This work aims to propose an integrated analysis methodology using an EBM approach that encompasses environmental variables and current and potential uses, contributing to the implementation of marine spatial planning for the inner continental shelf surrounding the Patos lagoon estuary. Datasets were used to produce the thematic maps, such as surface sedimentology, location of
\end{abstract}

the ecologically important submerged features, occurrence of mineral resources and zoobenthic fauna, with trophic importance and/or endangered. A sedimentological map was initially drawn; it was possible to observe the predominance of fine sand sediments between the coastal zone and the 50 meter isobaths, together with some coarse and medium quartzose sand and shell gravel deposits. The identification of these sedimentological patterns is fundamental in the understanding of the benthic communities, in addition to creating subsidies for the conservation of species. The present study proposes the creation of zones for exclusive use and multiple-use based on the surveys and mapping of the environmental and socioeconomic features of the region.

Keywords Ecosystem Approach, Inner Continental Shelf, Zoning Scheme, Integrated Analysis

\section{Introduction}

Marine and coastal ecosystems are considered habitats 
with complex interactions, providing ecologic, economic, and cultural benefits, as well as being the most productive and dynamic ecosystems around the globe [1,2]. Marine spatial planning (MSP) is an important management tool created to establish a more rational organization of the marine and coastal areas, equalizing the demands of development with the need to protect these ecosystems. The MSP's main goal involves the analysis and allocation of the spatial and temporal distribution of human activities [3].

Ecosystem-based management (EBM) is a methodological approach that emerged in the 1990s with the work of [4] and [5]. The authors discuss problems in relation to the management of marine and coastal resources by sector and highlight the ecological and socioeconomic problems from limited and imprecise information, emphasizing that the problems could be minimized or avoided by adopting an EBM approach. In the case of the marine environment, EBM is defined as an environmental management tool that recognizes the complete set of interactions within this realm including human activities, rather than considering only ecological issues, species, or services in an isolated way [6]. Growing awareness and formalization of the ecosystem approach emerged as a result of international environmental agreements in the United Nations framework, a fundamental description of this approach was formalized for the first time in the 1972 Stockholm Declaration [7].

Marine resources play a vital role in social and economic development for industries such as fishing, tourism, agriculture, pharmaceuticals, transport, and mining. However, increasing consumer needs and the advent of new technologies concomitant with the population growth rate have increased the dependence on these resources [8]. Therefore, there is a need to find a balance between different activities, sectors, and environmental sustainability in the use and management of the oceans.

In the early 2000s, the United Nations published the Millennium Ecosystem Assessment (MEA), an important program designed to meet the demands of decision-makers and the public, providing scientific information on the consequences of ecosystem changes and options on how to respond. This program focuses on ecosystem services and evaluating how the changes in these services affect human well-being and people in future decades. It also provides response options that can be adopted at different scales to improve ecosystem management and thus contribute to population well-being and poverty reduction.

Fast population growth, the technological developments, and the increasing needs of the population have increased the demand for more food, energy, and the implementation of other activities such as offshore aquaculture, whale-watching tourism, and the installation of structures for the generation of renewable energy [9]. Due to the reduction or limitation of certain resources in continental areas, there is a need for a greater supply of goods and services from coastal areas and resource extraction has been progressively expanded to deeper and more distant marine waters [10].

In addition to the risks related to the loss of ecosystem functions, the main concerns today are related to the impacts that activities occurring in the same area can generate in the marine environment and to the conflicts between human use and the marine environment. With limited resources in terms of space and quantity, economic development has already shown to be devastating in many places, raising competition among users and interest groups, resulting in increasingly unpleasing effects, including overfishing, habitat loss and destruction, pollution, climate change, and cumulative threats to the oceans as a whole [9].

Designating marine sites for specific uses is not a recent initiative; however, planning and managing these areas in a more comprehensive and integrated way is relatively new. Countries like the United States and the Philippines have adopted zoning to create protected marine areas $[11,12]$, in addition to China, who recently approved national legislation that requires the development of multiuse zoning plans for its entire territory [13].

In the exclusive economic zone (EEZ), Brazil has sovereign rights for the exploration and exploitation, conservation, and management of natural resources [14]. The southwestern Atlantic Ocean, which extends from Terra do Fogo $\left(55^{\circ} \mathrm{S}\right)$, Argentina, to Cabo Frio $\left(22^{\circ} \mathrm{S}\right)$, Brazil, is characterized as one of the most energetic and complex areas of the ocean, with intense mixing processes of water bodies, fronts, ocean-atmosphere interactions, and high biological productivity. There are also significant continental inputs on the SW Atlantic Ocean continental shelf from La Prata river and the Patos-Mirim lagoon system [15]. This high productivity has been found in several scientific studies carried out in recent decades in this region $[16,17,18,19]$.

This work aims to propose an integrated analysis methodology using an ecosystem-based management approach that incorporates environmental variables and current and potential uses, promoting the implementation of marine spatial planning for the inner continental shelf adjacent to the Patos lagoon estuary.

\section{Study Area}

The study area is sited in the southern Brazilian coast (RS state) along the inner continental shelf and surrounding the Patos lagoon estuary, bordered by the Albardão $\left(32^{\circ} 88^{\prime} \mathrm{S} / 52^{\circ} 50^{\prime} \mathrm{W}\right)$ and Conceição lighthouses $\left(31^{\circ} 77 \mathrm{~S} / 51^{\circ} 56^{\prime} \mathrm{W}\right)$, and up to the $100 \mathrm{~m}$ isobath (Fig. 1). 


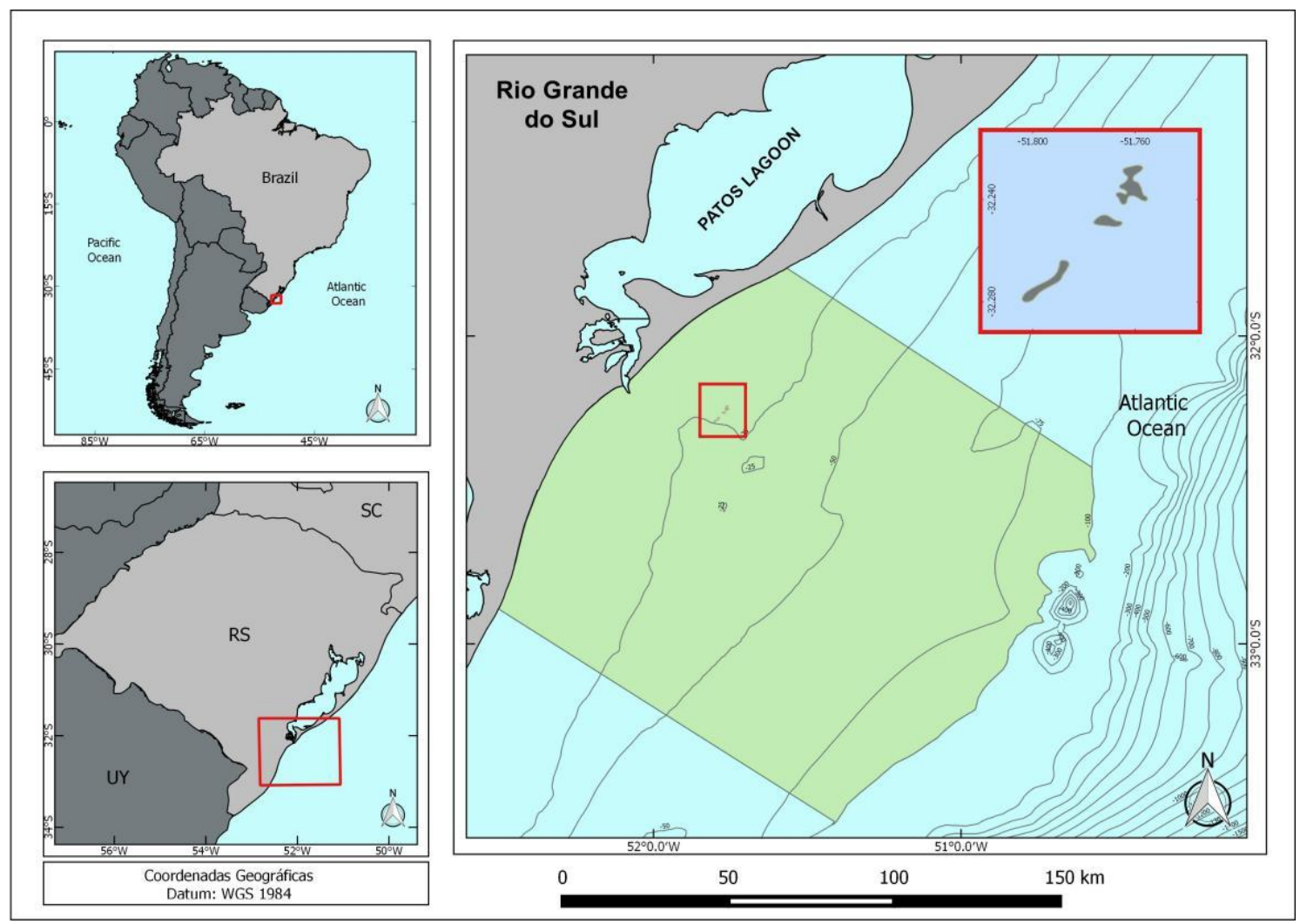

Figure 1. Study area in the southernmost Brazilian coast, emphasizing the Carpinteiro shoal.

This region presents specific use characteristics since it is a navigation route for large merchant ships that are traveling to the Rio Grande Harbor. The region is also used for other different activities, such as industrial fishing (gillnet and trawling), anchoring, and dredged disposal areas, as well as small tourist vessels [20].

It is important to mention the presence of a submerged feature known as the Carpinteiro beach rock shoal, which is located at a depth of approximately $20 \mathrm{~m}$ and approximately 15 nautical miles to the southeast of the mouth of the Patos lagoon estuary. This area contains beach rock shoals associated with shell gravel deposits and quartz fluvial coarse sand that represent relict sediments enfolded by fine sands with characteristics similar to the sands of beaches and dunes of the current coastal plain. Thus, the area is considered an ancient coastline [21].

The Carpinteiro beach rock shoal contains three shoals parallel to the coastline, with its origin related to the oscillations of the sea level during the Quaternary period. These oscillations drowned and reworked old coastline deposits generating the shoals due to the precipitation and cementation of calcium carbonate [22]. This feature confers ecosystem importance to the marine biota because this area is considered a feeding and reproduction area for several marine species $[23,24]$ and it is an important site for paleontological material [25,26,27].

Notably, the Municipal Conservation Unit Wildlife
Refuge (Municipal Law No. 007/96) is located at the eastern jetty at the mouth of the Patos lagoon estuary. In this place, populations of South American sea lion Otaria flavescens rest during their northward foraging trips, probably from the coast of Uruguay in winter and spring [28]. In addition, there is a gillnet fishing exclusion zone around the jetties and the adjacent marine and coastal area (INI $n^{\circ}$ 12/12) for the protection of the bottlenose dolphins Tursiops truncatus gephyreus [29]. Although located in the coastal region, these two protected areas would be under the indirect influence of activities that may occur in the adjacent ocean region, such as the exploitation of mineral resources or the selection of new areas for dredged material disposal, reinforcing the need to integrate these areas into the eventual authorizations for dredging and marine mining.

The southern Brazilian continental shelf (SBCS) presents a fairly continuous sediment distribution, with almost $90 \%$ of the inner portion being made up of predominantly quartz sand and shell gravel deposited in coastal environments [30,31]. The middle portion contains clay and silt of a terrigenous nature, is poor in sand, and was deposited in a past coastal lagoon, while the outer zone consists of relict gravel shell deposits containing mollusk and foraminifera shells and crustacean exoskeletons [32]. Oceanographic conditions in the SBCS are influenced by the Subtropical Convergence, which results from the interaction between the Brazil and 
Malvinas currents and between different water masses, especially the Tropical Water (TW), Sub-Antarctic Water (SAW), and South Atlantic Central Water (SACW) [33,34], as well as the Subtropical Shelf Water (STSW) and Sub-Antarctic Shelf Water (SASW), which are characteristic of this continental shelf region [15].

\section{Methodology}

The following datasets were used to create the thematic maps: a) surface sedimentology, from the Geological Oceanography Laboratory (IO-FURG) and the Center of Coastal and Oceanic Geology Studies (UFRGS); b) location of the Carpinteiro shoal (nautical chart DHN $\mathrm{N}^{\circ}$ 2110 of the Brazilian Navy); c) occurrence of mineral resources from the Geological Survey of Brazil (CPRM); and d) data on the zoobenthic fauna provided by the Ecology of Macroinvertebrates Laboratory (IO-FURG) and specialized bibliographical databases [35,36,37,38].

A sedimentological map was initially drawned based on the average grain size (i.e., Phi) and subsequent interpolation of the samples to obtain the spatial distribution of the sediments. A total of 994 sediment samples were loaded into the spatial analysis function of ArcGis $10.1{ }^{\circledR}$ and then interpolated using the natural-neighbor method. This method is used for regularly distributed stitch meshes for a better fit when not extrapolating values, solving the interpolation only within the data domain. The zoobenthic data were grouped separately, as follows: 1) total abundance of benthic fauna, 2) trophic important species (Loxopagurus loxochelis), and 3) threatened species (Astropecten cingulatus). For groups 1 and 2, the spatialized data were transformed into continuous surfaces using the kernel density estimator and then rescaled through normalization to a linear function with continuous values between 0 and 1 . For group 3 , a correlation analysis with the bathymetry and type of substrate was performed to infer possible occurrence areas [39].
This physical and biological information was later standardized into a single database in works the Quantum GIS software for generating thematic maps and then used in a multicriteria statistical analysis. In this method, all data related to the problem of interest were initially defined and then a variance matrix was established with subsequent ranking and analysis. The organization of these criteria into plans with equal information and spatial resolution was fundamental for the operation of image algebra since only matrices with 289 equal dimensions can be operated algebraically [40].

The identification of the most important criteria was necessary to validate the hierarchical analysis model and to point out the areas with a greater aptitude for conservation, mining, and multiple uses. This perspective views spatial analysis as a set of mathematical operations on maps, analogous to traditional algebra and statistical environments. In this study, the maps were treated as individual variables, and the functions defined on these variables were applied homogeneously to all points on the map.

\section{Results}

The present study showed a predominance of fine sands between the coastal zone and the $50 \mathrm{~m}$ isobath as well as some spots of coarse to medium sands and shelly gravel deposits (red color). Substrates with a large predominance of silt and clay were found in deeper areas and adjacent to the Patos lagoon mouth (Fig. 2). Geomorphological and sedimentary differentiation of the shoreface and inner shelf towards to the north of the Patos lagoon estuary jetties was also observed. This area has sandier bottoms, while to the south, there are muddier sediments. These characteristic differences demand different management actions by the environmental agencies such as the need for locational alternatives for the disposal of dredged material. 


\begin{tabular}{|l|}
\hline Sedimentological Classes \\
very Coarse Sand \\
Coarse Sand \\
Medium Sand \\
Fine Sand \\
Very Fine Sand \\
Coarse Silt \\
Medium Silt \\
Fine Silt \\
Very Fine Silt \\
Mud \\
\hline Isobaths \\
\hline Geographic Coordinates \\
Datum: WGS 1984
\end{tabular}

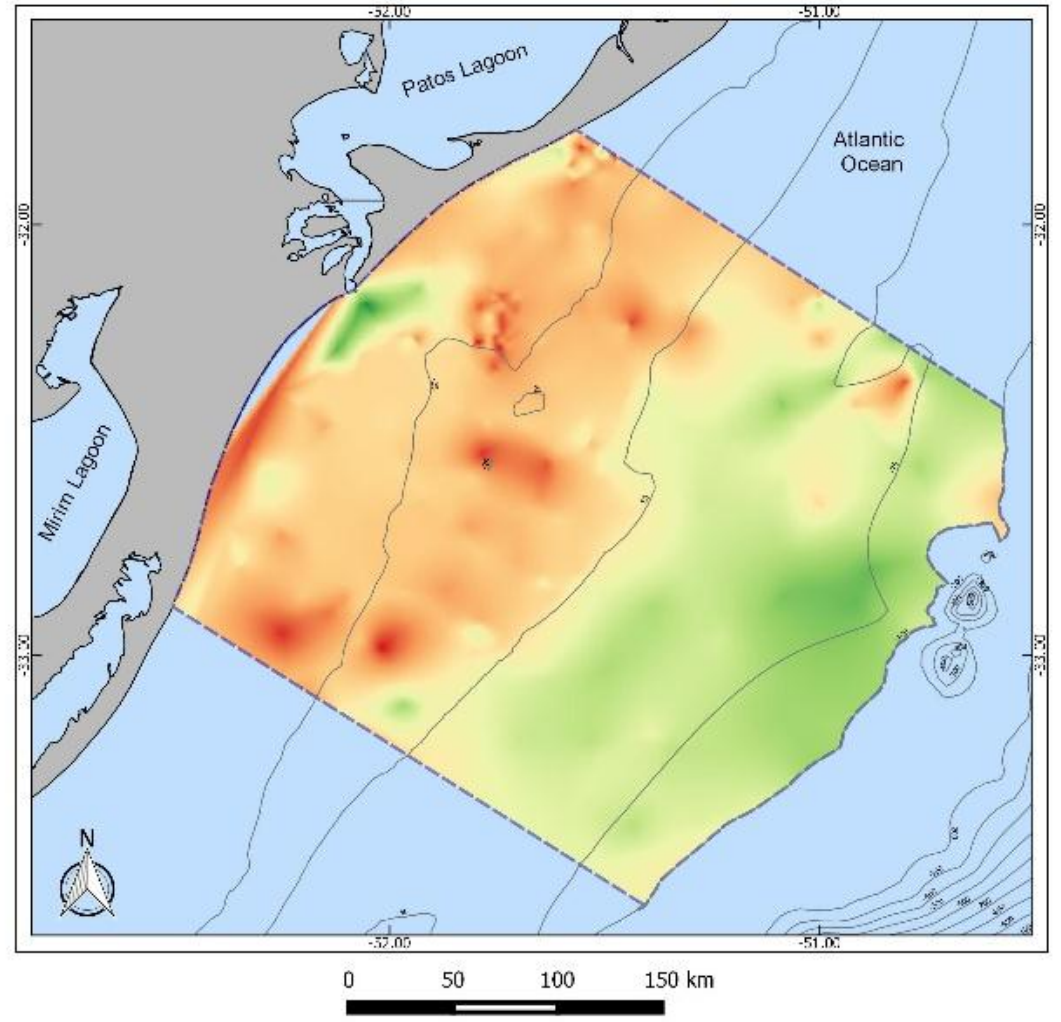

Figure 2. Map evidencing the spacial distribution of sediment classes within this portion of the SBCS.
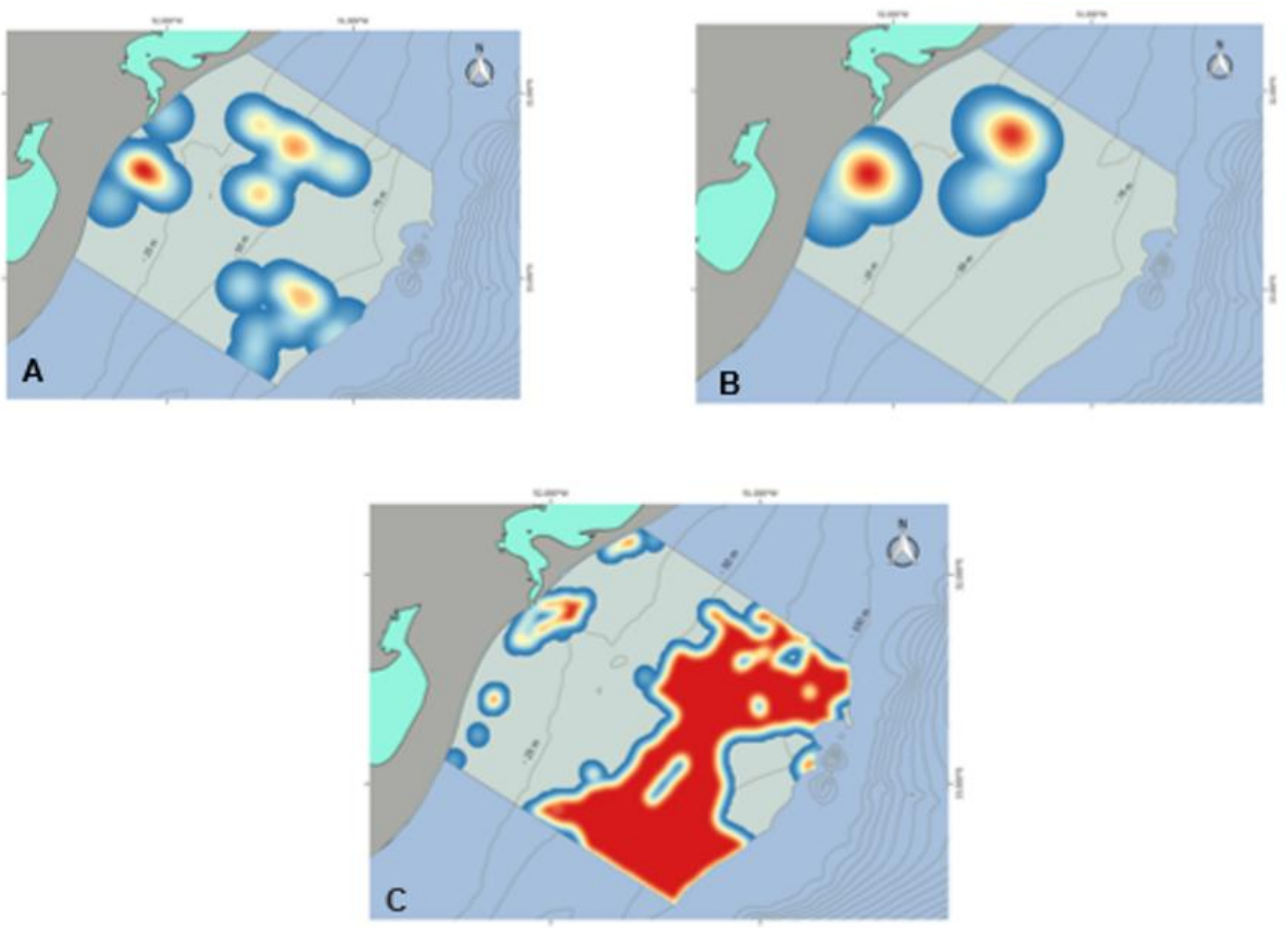

Figure 3. Kernel estimator (red: high; yellow: low; blue: no data) for total abundance (A) and trophic important species (B) within the study area, besides the projected occurrence area of the starfish A. cingulatus (C; red area). 
Figure 3 shows the spatial density related to the total abundance (Fig 3a) and trophic importance (Fig. 3b) of the benthic species recorded in the study area. It also shows the correlation between the sampling points for $A$. cingulatus and the type of substrate in which they were found, creating a projection of the area of potential occurrence for this species (Fig. 3c). This was possible because the substrate present in the projection area is mainly composed of sandy-silt sediments, the preferred environment for the species.

For the "Trophic importance" group, the decapod Loxopagurus loxochelis, also known as the hermit crab, stands out being quite common along the continental shelf of Rio Grande do Sul. This is due to the floor features around the Carpinteiro shoal, characterized by the presence of gravel deposits covered by fine sand with a high concentration of shells, favoring the occurrence of decapod crustaceans such as L. loxoceli.

Regarding the physical features, there is a significant occurrence of heavy minerals like ilmenite, monazite and zircon (light gray), and limestone composed of shell fragments (dark gray) along this inner portion of the SBCS, as can be seen in the Brazilian Legal Continental Shelf Atlas (APCJB), the Brazilian Geological Survey (Fig. 4). As to the aspects associated with sediments, there are mineral resources in the area of the inner shelf. They consist of limestone deposits associated with shell fragments (light gray), heavy minerals as a source of titanium, and siliciclastic sands for both civil construction and beach nourishment to stop coastal erosion (dark gray). In the near future, the limestone formed of shell fragments may represent the main resource.
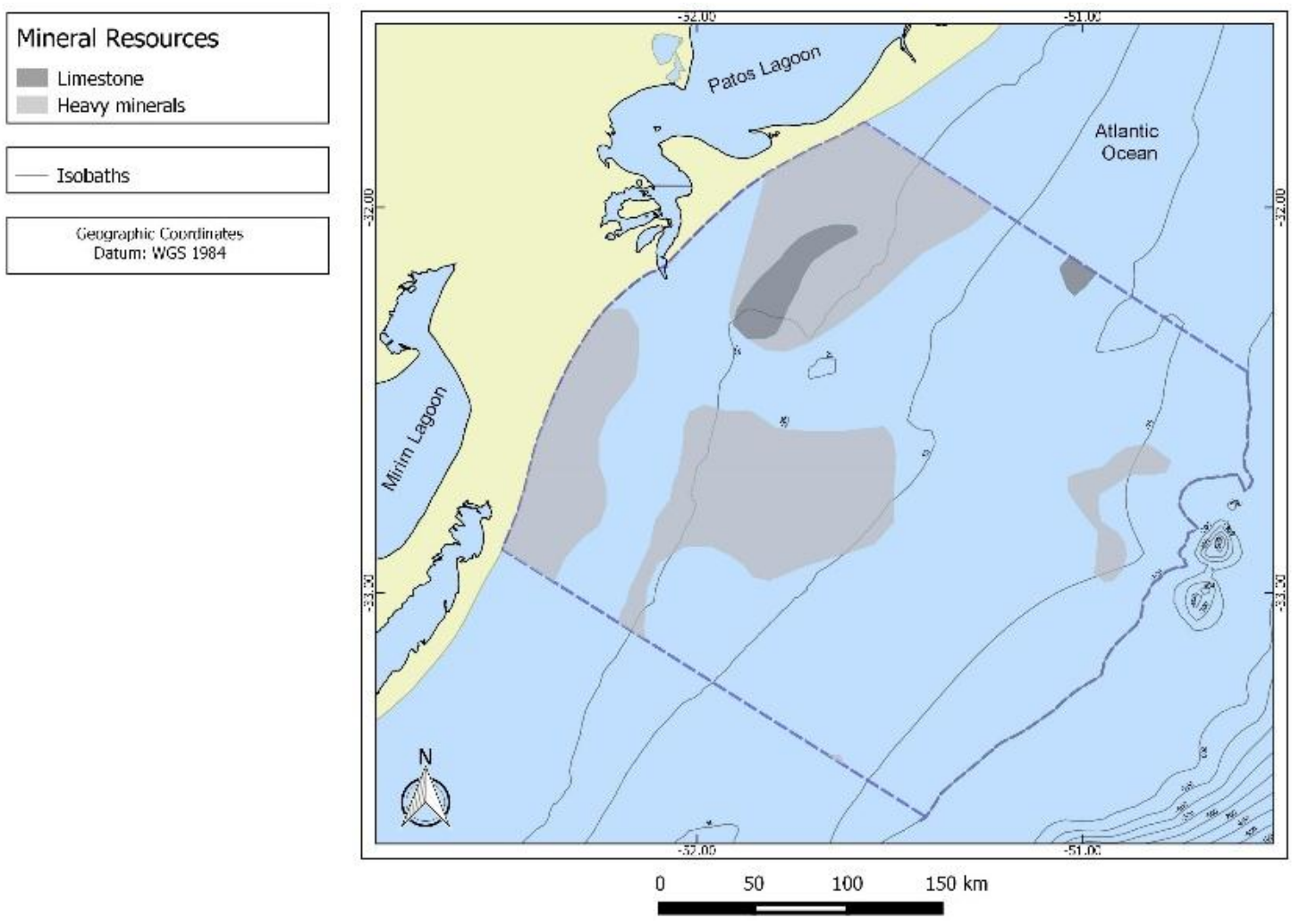

Figure 4. Location of mineral resources in study area. Source: [41]. 

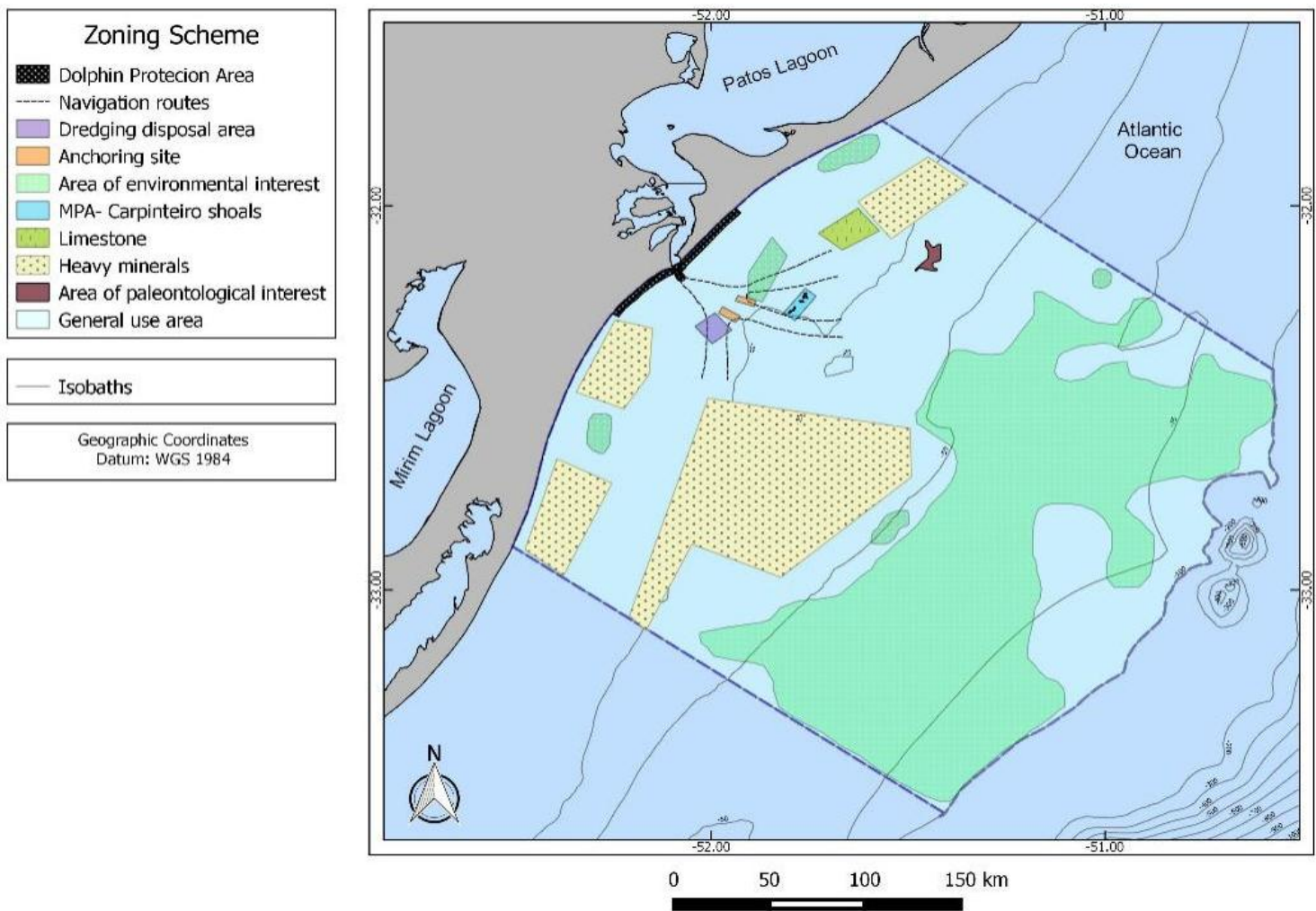

Figure 5. Proposal zoning scheme to the inner Continental Shelf of RS state through ecosystem-based approach

Taking into consideration the environmental characteristics detailed in these maps above and the economic activities present in the surrouding inner continental shelf of the Patos lagoon, this study proposes zoning for these activities (Fig. 5). The zones could be divided, for example, into exclusive use, such as environmental and paleontological interest and conservation protection areas, as well multiple-use, such as navigation routes, anchoring sites, and mineral exploitation. This map also shows the areas of high ecological importance; these are home to vertebrate and invertebrate fauna that are under of threat, for example fish, sea turtles, small cetaceans, and echinoderms, coexisting with current (fishing, navigation, dredging disposal areas) and future (mineral exploration) economic activities.

The creation of a Marine Protected Area (MPA) adjacent the Carpinteiro shoal would be essential in the preservation of the dusky grouper and the sea turtles that search for this marine feature to feed. It is also proposed as an area of environmental interest because it is home to the echinoderm, A. cingulatus, currently considered threatened.

\section{Discussion}

Adopting the precaution principle that "where there is a threat of substantial reduction or loss of biological diversity, the lack of full scientific certainty should not be invoked as a reason for delaying action to avoid or minimize such threat" [42], although there is a lack of further spatial-temporal data, the results presented so far in this study should prevent any possible conflicts between the conservation of species and anthropogenic activities occurring along this Atlantic continental shelf region.

The identification of sediment patterns is fundamental and considered to be one of the main factors determining the distribution and abundance of benthic fauna i.e., environments with a high variety of sediment types often present a high number of species [43]. The distribution and abundance of the benthic fauna along the continental shelf of Rio Grande do Sul state have been studied recently by several authors, using approaches related to factors that influence their distribution $[16,38,44]$ and relationship with environmental conditions [36].

Many benthic organisms are the major food items for some important commercial fishes $[45,46]$ and some endangered vertebrates like the dusky grouper Epinephelus marginatus (endangered), the narrow nose shark Mustelus schmitti (critically endangered), and the loggerhead sea turtle Caretta caretta, recently listed as threatened [47]. For instance, the starfish A. cingulatus, currently vulnerable according to the Red Book of the Brazilian Threatened Fauna, and the hermit crab $L$. loxochelis are both important food items of $C$. caretta [48]. 
Sandy mud substrates are the preferred environment for the starfish A. cingulatus [49], occurring in shallow waters up to $300 \mathrm{~m}[50,51]$. Shallow regions of the continental shelf are also inhabited by the hermit crab L. loxochelis, abundantly found along the Rio Grande do Sul shelf between $30^{\circ}-32^{\circ} \mathrm{S}[52,53]$. From GPS trackings it was possible to identify probable foraging areas for the loggerhead $C$. caretta near the coast (54), the same region in which L. loxochelis are abundant $[16,53,55]$.

In addition to hermit crabs, other crustaceans like the spider crab Libinia spinosa and gastropods of the genus Buccinanops are also recognized as important food items for the sea turtle [48], and are abundantly found in the vicinity of the Carpinteiro shoal [56]. This arenite shoal is covered by a diverse epibiota, remarkably by the soft coral Leptogorgia sp. (Rio Grande do Sul unique occurrence), and the macroalgae Rhodymenia delicatula, previously found only at the British Isles and the Mediterranean Sea [57]. The surroundings of this shoal are also important for Paleontology due to the fossil records of marine organisms (e.g. shark teeth and crustaceans) and bones of extinct terrestrial mammals [26] existing here. These records are essential tools for paleoecological and paleoenvironmental analyses [59].

Along this portion of the SW Atlantic continental shelf there is also the remarkable diversity of azooxanthellae corals between the 100-300 m isobaths but only one species - Astrangia rathbuni - is found along the inner shelf [60]. These non-reef building organisms are the keystone for both demersal and benthic communities, serving as a refuge, nursery, and feeding area [61] and can stabilize areas of unconsolidated substrate [62]. They are, however, severely threatened by demersal fisheries [60].

Another significant anthropogenic activity is the marine mining that takes place along the continental shelves worldwide. Results on mineral occurrence along the southern Brazilian, Uruguayan, and northern Argentinean continental shelves characterize the presence of heavy minerals in regions that have experienced marked influence from beaches or rivers in the past [63]. Marine mining requires environmental control measures and monitoring depending on the current environmental legislation. However, it is common to conduct environmental studies before and/or during projects, addressing issues of environmental impacts and the environmental sensitivity of an area, and proposing alternatives for removal and disposal as a way to reduce impacts [64].

Marine mining can cause both direct and indirect impacts to the benthic environment and its inhabitant biota, resulting in necessary preventive measures like the allocation of specific areas of concession and rigid control by government agencies as a way of mitigating the impacts $[65,66]$. Several studies have also addressed the question of the impacts caused by gravel, sand, and marine mineral mining on benthic communities in terms of habitat loss [67,68,69] and the subsequent recolonization of these impacted environments $[70,71,72,73]$.

The observed overlap between the dredged material disposal area and navigation routes is important to note. An analysis of the present work shows that the southern area of the Rio Grande jetties is a suitable site due to its substrate type, as well the predominance of main oceanic currents flowing to the south. This alternative site could avoid damage events, such as the largest mud deposition event recorded, occurring on a $13 \mathrm{~km}$ segment of Cassino Beach [74]. This extreme event was preceded by dredging and the disposal of the dredge spoils to a dumping site in the vicinity of the Rio Grande jetties [20].

Most studies focusing on marine landscape units have used the classification of benthic habitats as a way to subsidize integrated marine policies, either in support of spatial planning and use of natural resources or as an analysis tool for the creation of marine protected areas (MPAs). [75] used available geological, physical, hydrographic, and ecological data to produce important maps of the types of seascapes in the UK, including their distribution and extent, as a way to support the planning and management of certain types of uses of space and marine resources.

Knowledge about the spatial distribution of habitats is of fundamental importance to understand and limit anthropogenic pressures on the marine environment. Consequently, the mapping of these environments is increasingly considered as an effective means to comprehensively synthesize its spatial distribution and state, and to provide important information to environmental management applications $[3,76]$.

\section{Conclusions}

The present study proposes the creation of zones for exclusive use and multiple-use based on the surveys and mapping of the environmental and socioeconomic characteristics of the region. An integrated analysis of different activities and environmental characteristics of a given region is fundamental to defining priority areas for conservation and exploitation and thus, avoiding future conflicts. The oceanic region of the Patos lagoon estuary currently includes different anthropogenic activities, such as navigation, ship anchoring, disposal of dredged material, industrial fishing, and activities that occur over the medium and long term, such as marine mining.

Living and non-living marine resources are limited in space and abundance with increased pressure on the maritime environment resulting from the expansion of anthropogenic uses and activities, as well as the appearance of other uses increasing this problem. The ecosystem-based management approach applied in this study enabled the identification of areas with distinct 
functions and a proposal of actions to implement marine spatial planning, ensuring the sustainable use of marine and coastal resources, without compromising the current and future demands of society. In this context, MSP emerges as an essential tool to manage the development and use of marine and coastal resources in the most sustainable and integrated way.

\section{REFERENCES}

[1] Wilkinson C, Souter D. Status of Caribbean Coral Reefs after Bleaching and Hurricanes in 2005. Townsville, Australia: Global Coral Reef Monitoring Network, and Reef and Rainforest Research Centre. 2008.

[2] Yang X. Remote sensing and geospatial technologies for coastal ecosystem assessment and management. Springer-Verlag, Berlin. 2009.

[3] Ehler C, Douvere F. Marine spatial planning: a step-by-step approach toward ecosystem-based management. Intergovernmental Oceanographic Commission and Man and the Biosphere Programme, Paris. 2009.

[4] Griffis R, Kimball KW. Ecosystem approaches to coastal and ocean stewardship. Ecol. Appl.; 6(3): 708-712, 1996.

[5] Christensen NL, Bartuska AM, Brown JW, Carpenter S, D'Antonio C, Francis R, Franklin JF, Macmahon JA, Noss RF, Parsons DJ, Peterson CH, Turner MG, Woodmansee RG. The report of the Ecological Society of America Committee on the Scientific Basis for Ecosystem Management. Ecol. Appl; 6: 665- 691, 1996.

[6] Mcleod KL, Leslie HM. Ecosystem-Based Management for the Oceans. Island Press. 2009.

[7] Turrel WR. The policy basis of the Ecosystem Approach to fisheries management. Fisheries Research Services Internal Report No 02/04. 2004.

[8] Ansong J, Gissi E, Calado H. An approach to ecosystem-based management in maritime spatial planning process. Ocean Coast. Manag.; 141: 65-81, 2017.

[9] Douvere F. The importance of marine spatial planning in advancing ecosystem-based sea use management. Mar. Pol.; 32: 762-771, 2008.

[10] Berkes F, Hughes TP, Steneck RS, Wilson JA, Bellwood DR, Crona B, Folke C, Gunderson LH, Leslie HM, Norberg J, Nyström M, Olsson P, Österblom H, Scheffer M, Worm B. Globalization, Roving Bandits, and Marine Resources. Science; 311(5767): 1557-1558, 2006.

[11] White AT, Courtney CA, Salamanca A. Experience with Marine Protected Area Planning and Management in the Philippines. Coast. Manag.; 30(1): 1-26, 2002.

[12] Bates A.W. Revisiting Approaches to Marine Spatial Planning: Perspectives on and Implications for the United States. Agric. Resour. Econ. Rev.; 46(2): 206-223, 2017.

[13] Lu WH, Liu J, Xian XQ, Song WL, McIlgorm A. A comparison of marine spatial planning approaches in China:
Marine functional zoning and the marine ecological red line. Mar. Pol.; 62: 94-101, 2015.

[14] Fernandes LFS. O espaço marítimo brasileiro. In: Castello JP, Krug LC (eds). Introdução às Ciências do Mar. Pelotas, Editora Textos; 522-575, 2015.

[15] Piola AR, Matano RP. The South Atlantic Western Boundary Currents Brazil/Falkland (Malvinas) Currents. In: Steele JM, Thorpe SA, Turekian KK (eds.). Encyclopedia of Ocean Sciences. Academic Press; 340-349, 2001.

[16] Capítoli RR, Bemvenuti C. Distribuição batimétrica e variações de diversidade dos macroinvertebrados bentônicos da Plataforma Continental e Talude Superior no extremo sul do Brasil. Atlântica; 26(1): 27-43, 2004.

[17] Haimovici M. Sistemas pesqueiros marinhos e estuarinos do Brasil: caracterização e análise da sustentabilidade. Ed. Furg. 2011.

[18] Condini MV, Hoeinghaus DJ, Garcia AM. Trophic ecology of dusky grouper Epinephelus marginatus (Actinopterygii, Epinephelidae) in littoral and neritic habitats of southern Brazil as elucidated by stomach contents and stable isotope analyses. Hydrob.; 743: 109-125, 2015.

[19] Haimovici M, Cardoso LG. Colapso do estoque de Umbrina canosai do Sul do Brasil devido à introdução do arrasto-de-meia-água. Bolet. Inst. Pesca; 42(1): 258-267, 2016.

[20] Mirlean N, Calliari L, Johannesson K. Dredging in an estuary causes contamination by fluid mud on a tourist ocean beach. Evidence via REE ratios. Marine Pollution Bulletin; 159: 1-5, 2020.

[21] Calliari LJ, Esteves LS, Oliveira CP, Tozzi HAM, Silva RP, Cardoso JN. Padrões sonográficos e sedimentológicos de um afloramento de beachrock na plataforma interna do Rio Grande do Sul (COMEMIR/OSNLR). Notas Técnicas; 7: 27-32, 1994.

[22] Buchmann FSC, Seeliger M, Zanella LRC, Madureira LSP, Tomazelli LJ, Calliari LJ. Análise batimétrica e sedimentológica no estudo do Parcel do Carpinteiro, uma paleolinha de praia plesitocênica na antepraia atual do Rio Grande do Sul, Brasil. Pesq. Geoc.; 28(2): 109-115, 2001.

[23] Bugoni L, Krause L, Petry MV. Diet of sea turtles in southern Brazil. Chelon. Conserv. Biol.; 4(3): 685-688, 2003.

[24] Condini MV. Biologia reprodutiva, determinação de estrutura etária e crescimento da Garoupa-Verdadeira, Epinephelus marginatus (Lowe, 1834) em fundos rochosos no extremo sul do Brasil. Master thesis, FURG, 133p. 2012.

[25] Buchmann FSC. Distribuição dos fósseis pleistocênicos na zona costeira e plataforma continental interna no Rio Grande do Sul. Acta Geol. Leopold.; 17(39): 355-364, 1994.

[26] Buchmann FSC. Bioclastos de organismos terrestres e marinhos na praia e plataforma interna do Rio Grande do Sul: Natureza, distribuição, origem e significado geológico, Doctoral thesis, UFRGS 122 p. 2002.

[27] Lopes RP, Buchmann FSC. Pleistocene mammals from the southern Brazilian continental shelf. Jour. South Amer. Earth Scie.; 31: 17-27, 2011. 
[28] Rosas CW, Pinedo MC, Marmontel M, Haimovici M. Seasonal movements and distribution pattern of the southern sea lion Otaria flavescens (Shaw, 1800) off the Rio Grande do Sul coast, Brazil. Mammalia; 58(1): 51-59, 1994.

[29] Di Tullio JC, Fruet PF, Secchi ER. Identifying critical areas to reduce bycatch of coastal common bottlenose dolphins Tursiops truncatus in artisanal fisheries of the subtropical western South Atlantic. Endang. Spec. Res.; 29: 35-50, 2015.

[30] Corrêa ICS. Les variations du niveau de la mer durant les derniers 17.500 ans BP: l'exemple de la plate-forme continentale du Rio Grande do Sul-Brésil. Mar. Geol.; 130: 163-178, 1996.

[31] Figueiredo Jr AG, Tessler MG. Topografia e composição do substrato marinho da região Sudeste-Sul do Brasil. Instituto Oceanográfico da Universidade de São Paulo. Série Documentos REVIZEE/SCORE SUL, São Paulo, 1, 64. 2004.

[32] Mahiques MM, Mello e Sousa SH, Furtado VV, Tessler MG, Toledo FAL, Burone L, Figueira RCL, Klein DA, Martins CC, Alves DPV. The southern brazilian shelf: general characteristics, quaternary evolution and sediment distribution. Brazilian Journal of Oceanography. 58 (special issue PGGM): 25-34, 2010.

[33] Castello JP, Möller Jr OO. Sobre as condições oceanográficas no Rio Grande do Sul. Rev. Atlânt.; 2(2): 25 $-99,1977$.

[34] Ortega L, Martinez A. Multiannual and seasonal variability of water masses and fronts over the Uruguayan shelf. Jour. Coast. Res.; 23: 625-629, 2007.

[35] Zamponi MO. La distribuicion biocêanica y continua del género Renilla Lamarck, 1816 (Cnidaria, Pennatulacea) y su endemismo en el continente americano. Physis A58: 7-9, 2001.

[36] Capítoli RR, Bemvenuti C. Associações de macroinvertebrados bentônicos de fundos inconsolidados da Plataforma Continental e Talude Superior no extremo sul do Brasil. Atlântica; 26(1): 47-59, 2006.

[37] Souza KG, Martins LRS, Cavalcanti VMM, Pereira CV, Borges L. Recursos Não-Vivos da Plataforma Continental Brasileira e Áreas Oceânicas Adjacentes. Gravel; (Special edition): 86p, 2009.

[38] Pinotti RM, Martins MSL. The occurrence and ecology of Renilla spp. over the southwest Atlantic continental shelf $\left(28-34^{\circ} \mathrm{S}\right)$. Regional Studies in Marine Science; 34:1-6, 2020.

[39] Childs C. Interpolation surfaces in ArcGIS spatial analyst. ArcUser July/September: 32-35, 2004.

[40] Longley PA, Goodchild MF, Maguire DJ, Rhind DW. Geographic information systems and science. John Wiley and Sons, New York. 2001.

[41] Company of Mineral Resources Research - CPRM. Geologia e Recursos Minerais do Estado de São Paulo: Sistemas de Informações Geográficas (SIG). Programa Geologia do Brasil: Integração, atualização e difusão de dados da Geologia do Brasil. Mapas Geológicos Estaduais escala 1:750000, Brasília, (CD-ROM). 2008.
[42] Convention on Biological Diversity - CDB. Decision VII/5, AApp. 3 of the Conference of the Parties to the Convention on Biological Diversity, Kuala Lumpur, 9-20 February. Elements of a Marine and Coastal Biodiversity Management Framework. Marine and Coastal Biological Diversity. 2004.

[43] Herman PMJ, Middelburg JJ, Heip CHR. Benthic community structure and sediment processeson an intertidal flat: results from the ECOFLAT project. Contin. Shelf Res; 21: 2055-2071, 2001.

[44] Absalão RS. Environmental discrimination among soft-bottom mollusc associations off Patos lagoon estuary, South Brazil. Estuar. Coast. Shelf Sci.; 32: 71-85, 1991.

[45] Oliveira AF, Bemvenuti MA. Ciclo de vida de alguns peixes do estuário da Patos lagoon estuary, RS, informações para o ensino fundamental e médio. Cad. Ecol. Aqu.; 1(2): 16-29, 2006.

[46] Cardoso LG, Haimovici M. Density-dependent changes in the feeding behaviour of Macrodon atricauda of southern Brazil. Jour. Fish Biol.; 89(1): 01-07, 2016.

[47] Machado ABM, Drummond GM, Paglia AP. Livro vermelho da fauna brasileira ameaçada de extinção. Environment Ministry, Brasil. 2008.

[48] Barros JA. Alimentação da Tartaruga-cabeçuda (Caretta caretta) em habitat oceânico e nerítico no sul do Brasil: Composição, aspectos nutricionais e resíduos sólidos antropogênicos. Master Thesis, FURG, 118p. 2010.

[49] Carrera-Rodriguez CJ, Tommasi LR. Asteroidea de la plataforma continental de Rio Grande do Sul (Brasil), coleccionados durante los viajes del N/Oc. "Prof. Besnard" para el projecto Rio Grande do SuI. Bol. Inst. Ocean. USP; 26: 51-130, 1977.

[50] Clark AM. Notes on Atlantic Asteroidea (Ludiidae). Bull. Brit. Mus. Nat. Hist.; 42(3): 157-184, 1992.

[51] Ventura CRR, Fernandes FC. Bathymetric distribution and population size structure of paxillosid seastars (Echinodermata) in the Cabo Frio upwelling ecosystem of Brazil. Bull. Mar. Sci.; 56(1): 268-282, 1995.

[52] Rieger JP. Famílias Diogenidae e Paguridae. In: Buckup L, Bond-Buckup G (eds.) Os crustáceos do Rio Grande do Sul. Editora UFRGS. 1999.

[53] Berchieri NB. Distribuição e abundância de paguros e gastrópodes associados às áreas de forrageio de tartarugas marinhas na Bacia de Pelotas, sul do Brasil. Monography, FURG, 29p. 2016.

[54] Monteiro DS. Encalhes de tartarugas marinhas e uso de habitat por Caretta caretta no sul do Brasil. Doctoral thesis, FURG, 180p. 2017.

[55] Capitoli RR. Distribuição e abundância dos macroinvertebrados bentônicos da plataforma continental e talude superior no extremo sul do Brasil. Doctoral Thesis, FURG, 173p. 2002.

[56] Bauer W. Levantamento dos macroinvertebrados bentônicos do entorno do Parcel do Carpinteiro, RS - Brasil. Monografia, FURG, 39p. 2008.

[57] Horta PA, Morandini AC, Buchmann FSC, Oliveira EC. 
Macrobentos do Parcel do Carpinteiro - Um desafio para o levantamento da biodiversidade do Infralitoral do sul do Brasil, Anais da $13^{\circ}$ Semana Nacional de Oceanografia, Rio Grande, p. 126-127. 2001.

[58] Horta PA. Macroalgas do Infralitoral do sul e sudeste do Brasil: Taxonomia e Biogeografia, Tese de Doutorado, USP, 301p. 2000.

[59] Seddon AWR, Mackay AW, Baker AG, Birks HJB, Breman E. Looking forward through the past: identification of 50 priority research questions in palaeoecology. Jour. Ecol.; 102(1): 256-267, 2014.

[60] Kitahara MV, Capitoli RR, Horn Filho NO. Distribuição das espécies de corais azooxantelados na plataforma e talude continental superior do sul do Brasil. Iheringia; 99: 223-236, 2009.

[61] Mortensen PB. Aquarium observations on the deep-water coral Lophelia pertusa (Linnaeus, 1758) (Scleractinia) and selected associated invertebrates. Ophelia; 54(2): 83-104, 2001.

[62] Tommasi LR. Nota Sobre os Fundos Detríticos do Circalitoral Inferior da Plataforma Continental Brasileira ao Sul do Cabo Frio (RJ). Bol. Inst. Ocean. USP; 18(1): 55-62, 1970.

[63] Corrêa ICS, Ayup-Zouain RN, Weschenfelder J, Tomazelli LJ. Áreas Fontes dos Minerais Pesados e sua Distribuição sobre a Plataforma Continental Sul-Brasileira, Uruguaia e Norte-Argentina. Pesq. Geoc.; 35: 37-150, 2008.

[64] Souza KG, Martins LRS. Tecnologia de pesquisa, lavra e beneficiamento de recursos minerais marinhos. Parc. Estrat. I: 231-246, 2007.

[65] Earney CF. Marine mineral resources. New York: Routledge. 1990.

[66] Souza KG, Martins LRS, Cavalcanti VMM, Pereira CV, Borges L. Recursos minerais marinhos: fatos portadores de futuro, prioridades de estudo no Brasil e projetos estruturantes. Parc. Estrat.; 24: 247-261, 2007.

[67] Newell RC, Seiderer LJ, Hitchcock DR. The impact of dredging works in coastal waters: a review of the sensitivity to disturbance and subsequent recovery of biological resources on the seabed. Ocean. Mar. Biol. Ann. Rev.; 36: 127-178, 1998.

[68] Gomes AS, Palma JCC, Silva CG. Causas e consequências do impacto ambiental da exploração dos recursos minerais marinhos. Braz. Jour. Geoph.; 18(3): 447-454, 2000.

[69] Lodge M. Johnson D, Gurun GL, Wengler M, Weaver P. Seabed mining: International Seabed Authority environmental management plan for the ClarionClipperton Zone. A partnership approach. Mar. Pol.; 49: 66-72, 2015.

[70] Seiderer LJ, Newell RC. Analysis of the relationship between sediment composition and benthic community structure in coastal deposits: implications for marine aggregate dredging. Jour. Mar. Scie.; 56: 757-765, 1999.

[71] Sardá R, Pinedo S, Gremare A, Taboada S. Changes in the dynamics of shallow sandy-bottom assemblages due to sand extraction in the Catalan Western Mediterranean Sea. Jour. Mar. Scie.; 57: 1446-1453, 2000.

[72] Boyd SE, Limpenny DS, Rees HL, Cooper KM, Campbell S. Preliminary observations of the effects of dredging intensity on the re-colonization of dredged sediments off the south-east coast of England (Area 222). Estuar. Coast. Shelf Sci.; 57: 209-223, 2003.

[73] Boyd SE, Limpenny DS, Rees HL, Cooper KM. The effects of marine sand and gravel extraction on the macrobenthos at a commercial dredging site (results 6 years post-dredging). Jour. Mar. Sci.; 62: 145-162, 2005.

[74] Calliari LJ, Machado AA, Marroig P, Vinzon S, Gianuca N. Mud deposits at Cassino beach: role of dredging. Geo-Mar. Lett; 1-13, 2020.

[75] Connor DW, Gilliland PM, Golding N, Robinson P, Todd D, Verling E. UKSeaMap: the mapping of seabed and water column features of UK seas. Joint Nature Conservation Committee, Peterborough, 113 p. 2006.

[76] Cogan CB, Todd BJ, Lawton P, Noji TT. The role of marine habitat mapping in ecosystem-based management. ICES Journal of Marine Science.; 66(9): 2033-2042, 2009. 